nosocomial UTI. The same pattern was described in several European hospitals ${ }^{12}$.

\section{CONCLUSION}

This study suggests that if one could not wait the results of urine culture, the best choices to begin empiric treatment of nosocomial UTI are imipenem, second or third generation cephalosporin and aminoglycosides. Cefalothin and ampicilin are quite ineffective to treat these infections.

\section{REFERENCES}

1. Dieckhaus KD, Cooper BW. Infection control concepts in critical care. Crit Care Clin 1998; 14: 55-70.

2. Arosio A, Ferrari S, et al. Urinary tract infections in a general medicine department. Comments on cases collected over 3 years. Minerva Med 1986; 77(28-29): 1339-46.

3. Papapetropooulou M, Pagonopoulou O, Kouskouni E. Prevalence and sensitivity to antibiotics of Enterobacteriaceae isolated from urinary cultures in some microbiology laboratories of a city in west Greece. Patho Biol (Paris) 1997:45(9): 716-20.

4. Bronsema DA, Adams JR, Pallares R, Wenzel Rp. Secular trends in rates and etiology of nosocomial urinary tract infections at a University hospital. J Urol 1993; 150(2Part 1): 414-6.

5. Meares EM Jr. Nosocomial infection of urinary tract: changing pathogens, changing patterns. Urology 1985; 26(Suppl. 1): 2-4.

6. Rubinstein I, Rubinstein M. Infecção do trato urinário-aspectos gerais. In: Wroclawski ER, Bendhack DA, Damião R, Ortiz W, editors Guia Prático de Urologia. São Paulo: Editora Segmento; Rio de Janeiro: SBU-Sociedade Brasileira de Urologia, 2003: 3-6.

7. Prais D, Strussberg R. Bacterial susceptibility to oral antibiotics in community acquired urinary tract infection. Arch Dis Child 2003, 88: 215-8.

8. Kass EHFM. Assymptomatic infections of the urinary tract. Trans Assoc Am Physicians 1956; 69: 56-64.

9. Jones RN, Kugler KC, Pfaller MA, Winokur PL. The SENTRY Surveillance Group North America. Characteristic of pathogens causing urinary tract infections in hospitals in North-America: results from SENTRY Antimicrobial Surveillance Program, 1997. Diagn Microbiol Infect Dis 1999; 35: 55-63.

10. Vromen M, van der Ven AJ. Antimicrobia resistance patterns in urinary isolates from nursing home residents. Fifteen years of data reviewed. J Antimicrob Chemother 1999; 44: 113-6.

11. Jones RN. Impact of changing pathogens and antimicrobial susceptibility patterns in the treatment of serious infections in hospitalized patients. Am J Med 1996; 100(6A): $3 \mathrm{~S}-12 \mathrm{~S}$

12. Dornbusch K, King A, LegalisN. Incidence of antibiotic resistance in blood and urine isolates from hospitalized patients. Report from a European collaborative study. European Study Group on Antibiotic Resistance (ESGAR). Scand J Infect Dis 1998; 30(3): 281-8

13. Burven DR, Banerjee SN, Gaynes RP and the National Nosocomial Infections Surveillance System. Ceftazidime resistance among selected nosocomial gram-negative bacilli in the United States. J Infect Dis 1994; 170:1622-5

14. Rice LB, Eckstein EC. Ceftazidima-resistant Klebsilla pneumoniae isolates recovered at the Cleveland Department of Veterans Affairs Medical center. Clin Infect Dis 1996; 23:118-24.

15. Schiappa DA, Hayden MK. Ceftazidimaresistant Klebsiella pneumoniae and Escherichia coli bloodstream infection: A casecontrol and molecular epidemiologic investigation. J Infect Dis 1996; 174:529-36

Dias Neto JA, Silva LDM, Martins ACP, Tiraboschi RB, Domingos ALA, Suaid HJ, Tucci Jr S, Cologna AJ. Prevalência e susceptibilidade bacteriana da infecção urinária hospitalar. Acta Cir Bras [serial online] 2003 vol 18 suppl 4. Disponível em in www.scielo.org.br/acb RESUMO - Introdução: A infecção urinária é a mais comum das infecções hospitalares. O conhecimento da prevalência das cepas bacterianas e do antibiograma é importante para orientar a escolha inicial do antibiótico. Objetivo: Determinar a prevalência bacteriana e a sensibilidade aos antibióticos na infecção urinária hospitalar, em um hospital universitário, período janeiro-junho de 2003. Métodos: Foram analisados os prontuários de 188 pacientes com urocultura positiva $\left({ }^{3} 10^{5}\right.$ olônias/ml), depois de decorrido um período de pelo menos $48 \mathrm{~h}$ da internação. Resultados: Metade dos pacientes era homens. A idade média da amostra foi $50,2 \pm 22.7$ anos com variação de 3 meses a 88 anos. Em $80 \%$ dos casos a bactéria identificada era Gram-negativa. Os micróbios mais comuns foram E. coli $(26 \%)$, Klebsiella sp (15\%), P. aeruginosa (15\%) e Enterococcus sp (11\%). O antibiograma mostrou maior sensibilidade bacteriana ao imipenem $(83 \%)$, cefalosporinas de segunda e terceira geração e aminoglicosídeos e grande resistência à ampicilina e cefalotina. A sensibilidade foi baixa também para ciprofloxacina (42\%) e norfloxacina (43\%). Conclusão: Este estudo sugere que se não for possível aguardar os resultados da cultura e antibiograma a melhor escolha para início do tratamento seria o imipenem, cefalosporinas de segunda e terceira geração e aminoglicosídeos. A cefalotina e a ampicilina não constituem boa opção para o tratamento empírico inicial.

DESCRITORES: Infecção urinária. Etiologia, antibiograma. Infecção hospitalar. Microbiologia, sensibilidade.

\title{
Behavior of cholinesterase and liver mitochondrial function in dogs submitted to normothermic ischemia and reperfusion. ${ }^{1}$
}

\author{
Luis Pinto Fernandes2, Ajith Kumar Sankarankutty3, Eduardo Garcia Pacheco3, Sérgio Centurion3 \\ Maria Cecília Jordani3, Orlando de Castro e Silva Jr4
}

1. Estudo realizado no Laboratório de Bioquímica e Transplante Hepático do Departamento de Cirurgia e Anatomia da Faculdade de Medicina de Ribeirão Preto-Universidade de São Paulo (FMRP-USP)

2. Professor Doutor da Universidade do Distrito Federal, Brasília.

3. Pós Graduandos do Programa de Pós Graduação em Clínica Cirúrgica do Departamento de Cirurgia e Anatomia da FMRP-USP

4. Professor Associado do Departamento de Cirurgia e Anatomia 
Fernandes LP, Sankarankutty AK, Pacheco EG, Centurion S, Jordani MC, Castro e Silva Jr O. Behavior of cholinesterase and liver mitochondrial function in dogs submitted to normothermic ischemia and reperfusion.Acta Cir Bras [serial online] 2003 vol 18 suppl 5. Available in www.scielo.br/acb.

ABSTRACT - Purpose: The plasmatic activity of the cholinesterase (CHE) and the liver mitochondrial function, expressed by the ratio of respiratory control (RCR), were studied during normothermic ischemia. Methods: Sixteen adult mongrels, eight females and eight males were submitted to ischemia by clamping of the hepatic artery, portal vein and infrahepatic inferior vena cava, infrahepatic, for two h, follwed by reperfusion for $1 \mathrm{~h}$. The CHE and the mitochondrial function were evaluated at 60 and 120 min. of ischemia and at 15 and 60 minutes of reperfusion.Results: The CHE decreased, significantly, during ischemia and in reperfusion. The RCR was decreased at $120 \mathrm{~min}$. of ischemia, returning to the initial values on reperfusion.Conclusion:In this study, the CHE was a sensitive indicator of ischemic injury, suggesting irreversibility of ischemia injury. The RCR, by other side, showed a greater sensibility than the CHE in detection sense, during the studied period, the reversibility of the hepatic ischemic injury.

KEY WORDS: Cholinesterase. Mitochondral function. Passive venous bypass. Liver transplantation. Ischemia. Reperfusion.

\section{INTRODUCTION}

Several studies have been published regarding the hepatocellular biochemical and histological alterations during hepatic ischemia and reperfusion. Many of these alterations are studied in the hepatic tissue and, sometimes, alterations can be detected in the plasma $1,2,3,4,5,6,7,8$.

To analyse, experimentaly, the ischemia and reperfusion injuries of the hepatocytes some parameters can be used: the mitochondrial function, capacity to produce ATP, and the intracellular enzimatic contents released into the plasma.

The reversibility of ischemic injuries is related to cellular alterations after reperfusion, to celular capacity of ATP production and to the intracelular calcium contents regulation9. The CHE, a enzyme produced in the liver by the endoplasmic reticulum, is usually in high concentrations in the human plasma10,11,12.

Its reduced activity is considered a sign of hepatic perfusion reduction, shortage of proteic synthesis and associated with liver necrosis, with parenchyma reduction11, mainly in chronic liver diaseases, as cirrhosis and Kwashiorkor. The CHE would be related to the hepatic synthesis activity as well as the seric albumin10.

The hepatocyte mitochondrial function and its capacity to restore the energh production by the activation of glicolitic pathway during ischemia, has been studied as important indicators of irreversibility cellular injury2,13,14 .Its known that maintenance of cellular membrane potentialises an energy dependent process and that during ischemia, the content of hepatocyte ATP is reduced in minutes 15 .

Rhodes et al.13 showed that the hepatic ischemia needed to cause cellular death involves irreversible alterations in mitochondrial energetics functions. There is controversy whether irreversible mitochondrial injury precedes or whetherit is a late manifestation of cellular death. Its clear that duration of ischemic is a crucial factor in the reversibility of the process. 1

The purpose of this work is to investigate the alterations on CHE plasmatic activity, as well as the hepatocyte mitochondrial function during $2 \mathrm{~h}$ of ischemia and after $1 \mathrm{~h}$ of reperfusion, relating them to cellular viability. These parameters can be used as prognostic indicators in surgical procedures where the blood supply should be temporality interrupted, was well as for evaluating hepatic metabolic restoration after reperfusion in liver transplantation, hepatectomies and livers injuries.

\section{METHODS}

Sixteen adult mongrels, eighth females and eight males, weighing between 8 and 30 kilograms, were studied. All the surgical procedures were made in a normal temperature of $25^{\circ} \mathrm{C}$, with non-sterilised, but clean instruments. The animals were kept fasting for 24 hours before the surgery, with water "ad libitum" until 2 hours before anesthesia. The anesthetics used was sodium ethyl barbiturate (Nembutal - Abbot Lab.), 30 mg per kilogram of body weight, intravenously. The hepatic ischemia was produced by temporary clamping of the hepatic artery (HA), infrahepatic cava inferior vein, above the renal veins (CIV), porta vein (PV), with 2 hours duration. All dogs received heparine, $150 \mathrm{U}$ per kilogram of weight, endovenous, $10 \mathrm{~min}$. before the beginning of ischemial4.

The portal and inferior vena caval descompression was achieved by bypass of the femoral vein and the lateral and cranial branch of the splenic vein to the jugular vein, with the use of a siliconized and heparinized of polyvinyl tubing. At the end of the ischemic period, the splenic flux to the porta vein was kept by ligadure of its branch, keeping the splenic vein permeability. The arterial mean pressure and the central venous pressure were monitored by cateters introduced into femoral artery and into the external jugular, connected to the Physiograph - MK IV, from Narco Bio Systems. Liver biopsies were made before the ischemia, at 60 and $120 \mathrm{~min}$. of ischemia, and at 15 and 60 min. of reperfusion to study the mitochondrial function. Samples of venous blood were collected in heparinized glass tubes $(0,05 \mathrm{~mL}$ - Liquemine, Roche Lab, $5000 \mathrm{U} / \mathrm{mL}$ ) at the same periods.

Isolation of dog liver mitochondria. Mitochondria were isolated by conventional differential centrifugation 16 . The liver was immediately removed, washed in cold saline and homogenized three times at 1 min intervals in a Potter-Elvehjem homogenizer in $10 \mathrm{~mL}$ of a medium containing $250 \mathrm{mM}$ sucrose, $1 \mathrm{mM}$ EGTA, $10 \mathrm{mM}$ Hepes-KOH at $\mathrm{pH}$ 7.2. Homogenates were centrifuged at $770 \mathrm{~g}$ for 5 min and the resulting supernatant further centrifuged at $9.800 \mathrm{~g}$ for $10 \mathrm{~min}$. Pellets were suspended in $10 \mathrm{~mL}$ of a medium containing 250 $\mathrm{mM}$ sucrose, $0.3 \mathrm{mM}$ EGTA and $10 \mathrm{mM}$ Hepes$\mathrm{KOH}$ at $\mathrm{pH} 7.2$, and centrifuged at $4.500 \mathrm{~g}$ for $15 \mathrm{~min}$. The final mitochondrial pellet was suspended in $0.5 \mathrm{~mL}$ of a medium containing $250 \mathrm{mM}$ sucrose, and $10 \mathrm{mM}$ Hepes- $\mathrm{KOH}$ at $\mathrm{pH}$
7.2. All procedures were conducted at $4{ }^{\circ} \mathrm{C}$ and all solutions were prepared using glass-distilled and deionized water.

Protein determination. Mitochondrial protein content was determined by biuret reaction 17 .

Mitochondrial respiration. Mitochondrial respiration was monitored polarographically with an oxygraph equipped with a Clarck-type oxygen electrode (Gilson Medical Electronics, Middlenton, WI, USA). Assays were performed at $30^{\circ} \mathrm{C}$ using mitochondria $(1 \mathrm{mg}$ protein $/ \mathrm{mL})$ energized by $5 \mathrm{mM}$ a-ketoglutarate. Respiration media contained $125 \mathrm{mM}$ sucrose, $65 \mathrm{mM} \mathrm{KCl}$, $0.1 \mathrm{mM}$ EGTA, $1 \mathrm{mM} \mathrm{MgCl}, 2 \mathrm{mM} \mathrm{KH} 2 \mathrm{PO} 4$, and $10 \mathrm{mM}$ Hepes-KOH at $\mathrm{pH}$ 7.4. The state 3 respiration was induced with $400 \mathrm{nmol}$ ADP and state 4 respiration was determined after the phosphorylation of ADP. These respiratory parameters were expressed in $\mathrm{n}$ at. $\mathrm{O} / \mathrm{min} / \mathrm{mg}$ mitochondrial protein. The Respiratory Control Ratio (RCR),was determined by relation between the state 3 respiration and state 4 respiration ${ }^{18}$.

Determination of cholinesterasis activity. The plasma cholinesterasis activity study was made by colorimetric method18.

\section{Statistical analysis}

The Wilcoxon pared test was used with the significance level of $5 \%$. The absolute values of each experiment were enunciated as mean $(x)$ and standard error (se).

\section{Results}

The figure 1 shows the plasma cholinesterasis activity (U/L), mean and standard error, as well as the ratio of velocity the states 3 and 4 of mitochondrial respiration expressed by RCR, in animals before ischemia (C) at 60 (I1) and 120 (I2) minutes of ischemia and after 15 (R1) and 60 (R2) minutes of reperfusion.

The CHE plasmatic activity mean in the studied times was: 1278, 1093, 938, 777 and $736 \mathrm{U} / \mathrm{L}$. There was significant difference between the mean before ischemia (C) and the times I1, I2, $R 1$, and R2 ( $p<0,05)$. There wasn't difference, in statistical point of view, between R1 and R2 ( $p>0,05$ ). In relation to the RCR, the means were: 4,$8 ; 4,4 ; 3,4 ; 3,8$ and 3,9 . Significant reduction of RCR between times $\mathrm{C}$ and $\mathrm{I} 2$ ( $\mathrm{p}<$ $0,05)$ was observed. There wasn't also statistical differences between times C, I1, R1 and R2 $(\mathrm{p}>0,05)$. 


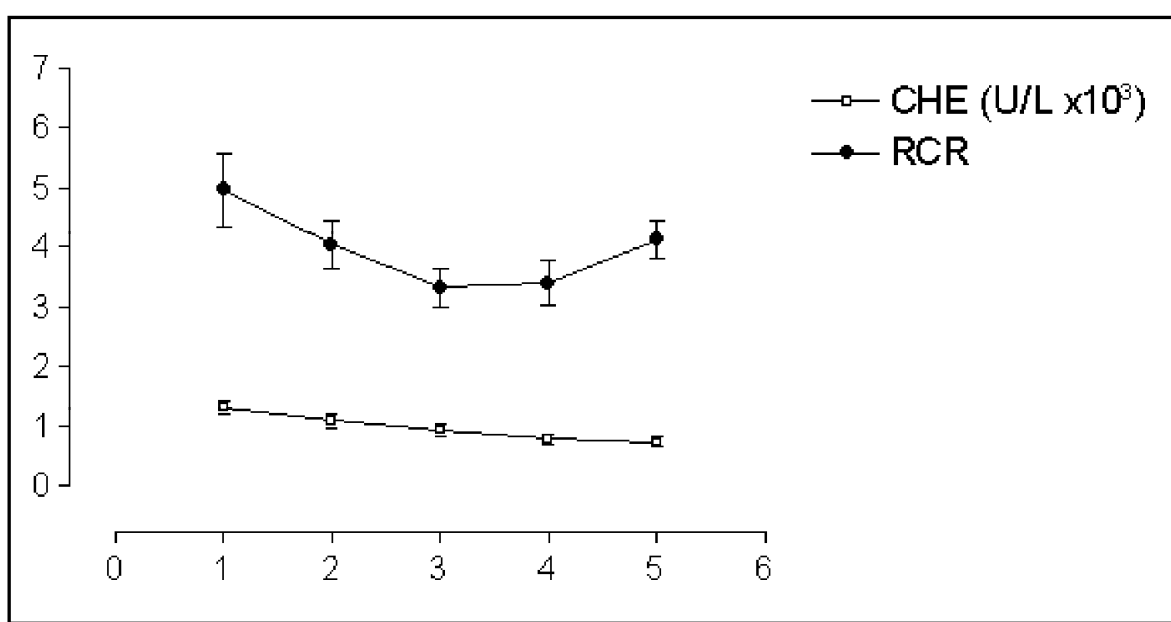

FIGURE 1 - The cholinesterase (CHE) plasmatic activity (U/L.103) and the respiratory contro ratio (RCR) before and during hepatic ischemia and after reperfusion $(\mathrm{X} \pm \mathrm{se})$.

$* \mathrm{p}<0,05$ (Wilcoxon test) vs other times.

\section{Discussion}

In this study, accentuated reduction in the plasmatic levels of the CHE was observed during ischemia and after reperfusion of the liver. This can be explained by the injuries caused during the two periods, with a consequent reduction of its synthesis. After reperfusion there was a significant reduction of the CHE, characterizing the injuries of ischemia and reperfusion.

The change in plasmatic enzymatic concentration expresses the cellular injury without relating to it is reversibility5. Consistent mitochondrial alterations occur after an interruption of the blood flow to different organs and the impossibility to reverse these disturbances are related to the incapacity of restructuring the cellular function $4,9,20$

The injuries from the reperfusion depends of the reestablishment of the blood flow and the amount of oxygen available to an organ previously ischemic or anoxic. There are tissue microcirculatory changes, just after the reperfusion, which result in some areas having no blood flow

Another aspect reperfusion injuries are the nocives chemical reactions involving free radicals derivated from oxygen that is introduced in to ischemic areas, causing cellular injury 8,10 .

The RCR showed a decrease in $\mathrm{I} 2$ with return to the initial values in $\mathrm{R} 2$, characterizing the reversibility of the injuries.

After half an hour of ischemia few or no evidence of histological cellular death was observed after 24 hours of reperfusion3. Nevertheless, after 2 to 3 hours of ischemia there was extensive necrosis compromising the membrane function, calcium pump and the capacity to produce ATP disturbances in phospholipid metabolism which can be detected as membrane disfunction.

The present study showed that CHE is a sensitive indicator of ischemia and reperfusion injury, in the time studied. Probably, 60 minutes was insufficient to the liver could resyntesized the CHE, by other side, the mitochondrial function showed a greater sensitivity than the CHE, during the period studied, to detect the reversibility of the hepatic ischemic injury

\section{REFERENCES}

1. Bernelli-Zazzera A, Gaja G. Some aspects of glycogen metabolism following reversible of irreversible liver ischemia. Exp Mol Pathol 1964; 3: 351-68.

2. Farkouh EF, Daniel AM, Beaudoin JG. Predictive value of liver biochemistry in auto hepatic ischemia. Surg Gynecol Obstet 1971; 132: 832-38.

3. Chien KR, Farber JL. Microsomal membrane dysfunction in ischemic rat liver cells. Arch Biochem Biophys 1977; 180: 191-8.

4. Farber LJ, Martin JT, Chien KR. Irreversible ischemic cell injury: prevention by chlorpromazine of the aggregation of the intramembranous particles of rat liver plasma membranes. Am J Pathol 1978; 92 713-32.

5. Fredericks WM, Myagkaya GL, Bosch KS. The value of enzyme leakage for the prediction of necrosis in the liver ischemia. Histochemistry 1983; 78: 459-72.

6. Reichling JJ, Kaplan MM. Clinical use of serum enzymes in liver disease. Dig Dis Sci 1988; 33: 1601-14.
These same authors showed that ischemia induces
7. Radziuk J. Metabolic function of liver: carbohydrates. In: Liver Function 1990 (Cramp DG, Carson ER, eds.), London, Chapman and Hall, 106-51.

8. Kobayashi, H, Nonami, T, Kurokawa T. Mechanism and prevention of ischemiareperfusion- induced liver injury in rats. $\mathrm{J}$ Surg Res 1991; 51: 2400-4.

9. Mittnacht Jr S, Farber JL. Reversal of mitochondrial of cholinesterase. J Biol Chem 1981; 256: 3199-206.

10. Kutty KM. Review: biological function of cholinesterase. Clin Biochem 1980; 193: 265-75.

11. Schmidt E. Estratégias e avaliação das determinações enzimáticas no soro em doenças do fígado e do sistema biliar. In: Avaliação da doença hepática 1980; (Demers LM, Shaw LM, eds.), Rio de Janeiro, Interamericana, 71-91.

12. Berninsone, $\mathrm{P}$, Katz E, Napp $\mathrm{M}$. Acetylcholinesterase and nonspecific cholinesterase activities in rat liver: subcellular localization, molecular forms, and some extraction properties. Biochem Cell Biol 1989; 67: 817-22.

13. Rhodes RS, DePalma RG, Druet RL. Reversibility of ischemically induced mitochondrial dysfunction with reperfusion. Surg Gynecol Obstet 1977; 145: 719-24.

14. Kono I, Ozawa K, Tanaka J. Significance of mitochondrial enhancement in restoring hepatic energy charge after revascularization of isolated ischemic liver. Transplantation 1982; 33: 150-5.

15. Jennische E. Effects of ischemia on the hepatic all membrane potential in the rat: differences between fed and fasted animals. Acta Phisiol Scand 1983; 118: 69-73.

16. Pedersen PL, Greenawalt JW, Reynafarje B, Hullihen J, Dercker GL, Soper JW, Bustamente E. Preparation and characterization of mitochondria and submitochondrial particles of rat liver and liver derived tissues. Methods Cell Biol, 1978 20: 411-81.

17. Cain K, Skilleter, DN. Preparation and use of mitochondria in toxicological research.In Snell K, Mullock B. Biochem Toxicol 1987.Oxford IRL Press, 217-54.

18. Chance B, Williams GR The respiratory chain and oxidative phosphorilation. Adv Enzimol 1956; 17: 65- 134

19. Ellma GL, Courtney KD, Featherstone RM. A new and rapid colorimetric determination of acetylcholinesterase activity. Biochem Pharmacol 1961; 7: 88-95.

20. Fath JJ, Cyr JAS, Konstantinides FN Alteration of amino acid clearence during ischemia predict hepatocellular ATP changes. Surgery 1985; $98: 396-404$.

Fernandes LP, Fernandes LP , Pacheco EG, Centurion S, Jordani MC, Castro e Silva Jr O. Colinesterase e função mitocondrial hepática em cães submetidos a isquemia normotérmica e reperfusão do fígado.Acta Cir Bras [serial online] 2003 vol 18 suppl 5. Disponível em www.scielo.br/acb.

RESUMO- Objetivo : A atividade plasmática da colinesterase (CHE) e a função mitocondrial do fígado expressa pela RCR- razão de controle respiratório mitocondrial foram estudadas durante a isquemia/reperfusão hepáticas. Métodos: Dezesseis cães adultos sem raça definida (oito machos e oito fêmeas) foram submetidos a isquemia normotérmica por pinçamento do pedículo hepático e da veia cava inferior infra-hepática por 2 horas, seguida de 15 e 60 minutos de reperfusão.A CHE e a RCR foram avaliadas após 60 e 120 minutos de isquemia e após 15 e 60 minutos de reperfusão.Resultados : Os níveis de CHE diminuíram significativamente na isquemia e 
reperfusão.A RCR diminuiu após 120 minutos de isquemia retornando a níveis semelhantes ao controle após a reperfusão. Conclusão: A CHE foi sensível para indicar a lesão isquêmica, sugerindo irreversibilidade da lesão. Já a RCR foi mais sensível no sentido de detectar a reversibilidade da lesão isquêmica após a reperfusão.

DESCRITORES: Colinesterase. Função mitocondrial.Transplante de fígado.Isquemia. Reperfusão.

Correspondence to:

Orlando Castro-e-Silva Jr Conflito de interesse: nenhum.

Fonte de financiamento:FAPESP

Rua Campos Salles 890, 9 andar Cep: 14015-110

Centro, Ribeirão Preto, São Paulo, Brazil.

$55166022871 / 55166100626$

Email: orlandocsj@hotmail.com

15 - ARTIGORETROSPECTIVO

\section{Adrenalectomia laparoscópica: análise de 11 pacientes $^{1}$}

Ricardo Brianezi Tiraboschi², André Luis Alonso Domingos², Rodolfo Borges Reis ${ }^{3}$, Tiago Borelli Bovo ${ }^{2}$ Haylton Jorge Suaid ${ }^{3}$, Adauto José Cologna ${ }^{3}$, Antonio Carlos Pereira Martins ${ }^{3}$

Tiraboschi RB, Domingos ALA, Reis RB, Bovo TB, Suaid HJ, Cologna AJ, Martins ACP. Adrenalectomia laparoscópica: análise de 11 pacientes. Acta Cir Bras [serial online] 2003 vol 18 suppl 5. Disponível em www.scielo.br/acb

RESUMO - Objetivo: Analisar a experiência inicial da Divisão de Urologia do HCFMRP-USP na adrenalectomia transperitoneal videolaparoscópica. Métodos: Análise retrospectiva de 11 casos de adrenalectomia transperitoneal laparoscópica realizados de fevereiro de 1999 a março de 2003 sendo 3 em homens( 27\%) e 8 em mulheres (73\%), idade média de 40,2 $\pm 13,1$ anos. Os pacientes apresentavam os diagnósticos seguintes: adenoma -5 , síndrome de Cushing -3 , feocromocitoma - 1, hiperaldestorismo - 1 e síndrome de Carney - 1. Resultados: A cirurgia foi bilateral em 05 pacientes $(45,4 \%)$ e unilateral em 06 pacientes $(54,6 \%)$, destes 04 à direita $(36,4 \%)$ e 02 à esquerda $(18,2 \%)$. O tempo médio de internação foi de $3,6 \pm 1,1$ dias, o tempo médio de cirurgia foi de $220,5 \pm 103,7$ minutos e a taxa de conversão foi de $18,2 \%$. Conclusão: Os resultados apresentados são similares aos relatados pela literatura, demonstrando que a adrenalectomia videolaparoscópia pode ser realizada de maneira segura e eficiente com benefícios: tempo cirúrgico aceitável, rápida recuperação pós-operatória e alta precoce.

DESCRITORES: Adrenalectomia, laparoscopia. Adenoma da adrenal. Cushing. Conn. Carey.

\section{INTRODUÇÃO}

O uso de técnicas minimamente invasivas tem mudado o acesso cirúrgico à glândula adrenal. Desde sua primeira descrição, em 1991 por Gaygner ${ }^{1}$, a adrenalectomia videolaparoscópica tem se difundido com ampla aceitação mundial ${ }^{2}$. Antes do advento da laparoscopia o acesso cirúrgico tradicional geralmente se fazia por ampla incisão na pele para exposição adequada de um órgão pequeno e friável com abundante e delicada vascularização, situada no retroperitô$n^{n}{ }^{3}$. Na última década vários trabalhos foram publicados a respeito dos benefícios da adrenalectomia videolaparoscópica ${ }^{2,4,5}$. Atualmente é considerada o tratamento padrão para a maioria dos pacientes com patologias cirúrgicas da adrenal, incluindo tumores e o feocromocitoma ${ }^{4,5}$. O procedimento está associado com menor período de convalescência, menor dor pós-operatória, internação hospitalar reduzida e retorno precoce à atividade funcional do paciente ${ }^{6}$. O objetivo deste trabalho é mostrar a experiência inicial da disciplina de Urologia do HCFMRP-USP.

\section{MÉTODOS}

Análise retrospectiva dos casos de adrenalectomia laparoscópica realizada de fevereiro de 1999 a março de 2003 no HCFMRP-USP. Os procedimentos foram realizados via transperitoneal. Os pacientes foram posicionados em decúbito lateral. O pneumoperitôneo foi obtido com punção abdominal com agulha de Veress e insuflado dióxido de carbono (CO2) na pressão de 12-14 mmHg. $\mathrm{O}$ acesso à cavidade peritoneal foi obtido inicialmente através de uma pequena incisão transversa situada na linha medioclavicular na altura da cicatriz umbilical, onde foi inserido trocarte de $10 \mathrm{~mm}$ e colocado a câmera. Três portes adicionais de 5 ou $10 \mathrm{~mm}$ foram então colocados: na linha médioclavicular aproximadamente dois dedos abaixo da margem costal, na linha axilar anterior na altura da cicatriz umbilical e linha axilar posterior.

$\mathrm{Na}$ dissecção laparoscópica, numerosas pequenas artérias e veias são encontradas e devem ser controladas tanto por eletrocauterização ou clipagem pois as adrenais têm suprimento sanguíneo extremamente rico com ramos arteriais da aorta, artéria frênica inferior e artéria renal. A veia adrenal origina-se na medula e desemboca na veia cava no lado direito e na veia renal do lado esquerdo ${ }^{3}$

$\mathrm{Na}$ adrenalectomia direita o peritôneo é incisado e rebatido inferiormente, o fígado afastado para exposição adequada. A dissecção da glândula adre- nal direita começa inferior e lateral onde o tecido fibroadiposo contém pequenos vasos que são controlados. A veia adrenal entrando na veia cava é identificada e dissecada precocemente, é então duplamente ligada com clipes metálicos e seccionada. A dissecção prossegue superiormente no tecido adiposo entre a glândula adrenal e a face lateral da veia cava inferior, os vasos encontrados são cuidadosamente ligados. A musculatura póstero-inferior do diafragma pode ser vista neste ponto. A dissecção continua inferiormente até a face ínfero-medial da glândula quando é liberada da fáscia de Gerota. A glândula adrenal é removida num saco endoscópico através de um dos portes. É realizada então a revisão da hemostasia.

Para o acesso à adrenal esquerda, a flexura esplênica deve ser incisada e o cólon rebatido inferiormente, geralmente o baço não necessita de afastamento. A dissecção do tecido ao redor da face posterior da cauda do pâncreas ajuda a definir a borda anterior da adrenal esquerda. A dissecção continua póstero-inferiormente no tecido fibroadiposo entre a adrenal e o rim e prossegue anteriormente com atenção para a localização da veia adrenal esquerda.

Os diagnósticos estão apresentados na Tabela 1 . Nenhum dos tumores apresentava diâmetro superior a $4 \mathrm{~cm}$.

1. Pesquisa realizada no Hospital das Clinicas - FMRP-USP

2. Medico Residente de Urologia / Hospital das Clinicas - FMRP-USP

3. Professores e Assistentes de Urologia Hospital das Clinicas - FMRP-USP 